Kohl: a Journal for Body and Gender Research

Vol. 6, No. 1 (Summer 2020)

\title{
Sex Workers as Workers: A Critique of Abolitionist Approaches to Sex Work in Lebanon
}

\author{
Ali Reda
}

\begin{abstract}
:
The abolitionist view on sex work in Lebanon paints it as solely the outcome of male buyer's desire to purchase sex. This portrayal obfuscates serious and important contingencies that often precipitate sex work that is precarious: increased commodification of social relations and the failure of state and kin entities to provide for all its members in a just manner. Seeing sex work as a labour problem allows for a greater contextualisation, which once explored, points to the need to strengthen sex worker's labour conditions rather than constraining them by punishing buyers. I carry this analysis into three domains relating to sex work. The first is the link between sex work and sex trafficking that abolitionists such as Kafa take for granted. While it might be beneficial to study the two as part of the same continuum, we must remain cognizant of what makes "work" into "slavery" instead of collapsing the two. The second and third part of the essay look at Kafa's 2014 report from two sections: its diagnosis of the problem and its proposed solution. The diagnosis they layout portrays the problem as the problem of demand that creates the conditions of sex work and thus offers the solution of criminalising the buyer. This "Nordic model," I show, has limited opportunities in Lebanon.
\end{abstract}




\section{Introduction}

An article published last year by Imad Bazi retells Beirut's hidden history of sex workers and patrons (2019). Ifaf was one of the many patrons of pre-civil war Beirut. But before she became a patron, she was a famous sex worker in the forties, during the first decade of the industry's legalisation under the French mandate. She reached extreme levels of notoriety when a jealous competitor attacked her using a corrosive agent. She knew then that she was not safe within Beirut's dark alleys. Ifaf decided that her chances were better off marrying a Lebanese security official who would provide her with a home and protection. From her newly earned status, she was able to bring along several other women into her patronship.

Eventually, Ifaf and her husband, as per Bazi's narrative, came to attract women who ran away from their parent's house, tricked others into joining her, and even unknowingly harboured the famous Israeli spy Shulamith Cohen in her brothel. Her story ends with her arrest during an anti-sex work raid in the late fifties. Eventually, Bazi mentions that she led a prison riot against conditions in the Baabda women's prison, becoming more of a comrade among women rather than their patron.

Ifaf's story, while at least in part mythologised, reveals how the state and state agents play a great deal in legalising, regulating, and abating the modus operandi of sex work. Ifaf's decision to become a sex worker might have been her own. But it was the lack of safety measures and protection that pushed her into the folds of corrupt security officials. Ifaf was also entirely dependent on the provision of unemployed, young women to bankroll her patrimony. The rapid increase in unemployment in an economy catered for financial services based on nepotistic employment, which later precipitated the civil war, undoubtedly helped Ifaf persuade these women to join her (Nasr, 1978, p. 11). It is a telling story of how the state and its absence structure the conditions of sex work in Lebanon.

It is this context that I aim to raise against what I term "abolitionist" approaches to sex work. The abolitionist view treats sex work as a homogeneous expression of patriarchal desire that dominates and exploits the sexuality of the sex worker. For the abolitionist, transacting in sex provokes tremendous moral trepidation, reproduces patriarchal notions on the worthiness of those selling sex, and leads to the degradation of the body of the seller. Sex work is deemed a job that corrupts the body and psyche of client and seller alike. Against this moralistic approach, I argue that the most prevalent forms of sex work in Lebanon (run by a patron, and often under the indirect regulation of the state, the police, and their apparatuses) emerge from the failure of traditional modes of kinship and socioeconomic relations. Indeed, these systems of kinship and employment do not provide people with meaningful work or any mechanisms of self-fulfillment. When studying sex work, one cannot understand it as a process that exists outside the web of the political, economic, and social matrix that it exists within. That is, instead of seeing sex work as the source of patriarchal ideas when it comes to those who participate in the industry, I see the industry itself to be a response to the failures of the Lebanese state. To transform "sex work" into a given social phenomenon that impacts sociality is to fundamentally redraw how people come to transact in sex and bodies, to begin with. For it is often the patriarchal conception that women's sexuality is the property of their agnates that propels to reclaim it for themselves as sex workers. 
To concretise my critique, I point to Kafa's 2014 report on sex work in Beirut, Exploring the Demand for Prostitution, as a pertinent example of the abolitionist portrayal of sex work. Since the paper deals with a report on sex work among cis-women, I build on examples on parallel manifestations of the phenomenon. Hence, I deal with sex work largely as a transaction of sexual services between a cis-woman and a client although that obviously doesn't represent the breadth of 'sex work' writ large.

My main argument is that the abolitionist view on sex work lacks contextualization within the patriarchal relations and weak labour conditions in Lebanon, and paints it as solely the outcome of male buyer's desire to purchase sex. This portrayal obfuscates serious and important contingencies that often precipitate sex work that is precarious: increased commodification of social relations and the failure of state and kin entities to provide for all its members in a just manner. I start this essay by reviewing feminist debates on sex work, pointing to how there's been a tendency to fixate on the value of sex as a social phenomenon rather than the dimension of labour within sex work. Seeing sex work as a labour problem allows for a greater contextualisation, which once explored, points to the need to strengthen sex worker's labour conditions rather than constraining them by punishing buyers. I carry this analysis into three domains relating to sex work. The first is the link between sex work and sex trafficking that abolitionists such as Kafa take for granted. I argue here that while it might be beneficial to study the two as part of the same continuum, we must remain cognizant of what makes "work" into "slavery" instead of collapsing the two. The second and third part of the essay look at Kafa's 2014 report from two sections: its diagnosis of the problem and its proposed solution. The diagnosis they layout portrays the problem as the problem of demand that creates the conditions of sex work and thus offers the solution of criminalising the buyer. This "Nordic model," I show, has limited opportunities in Lebanon.

\section{Sex or Work?}

Despite extensive debates on sex work in feminist scholarship, the topic remains one of the least empirically documented, especially in accounts that provide an otherwise distinctly negative or empowering interpretation of sex work and women's agency (Rubin, 1993; Weitzer, 2009). This divide has structured the feminist debate for several decades without centralising the subjects of the research. Indeed, the debate played a significant part in delineating the feminist debates on the sociological problem of agency and structure while at the same time removing itself from the reality of people involved in the industry. Reducing the question to one of whether women "honestly" choose sex work and whether consent is at all possible in the condition of absolute poverty is how this debate unfolded.

Seeing the issue as one of structure or agency is a problem of its own, nonetheless. This formulation risks excluding the reason for instigating such discussions in the first place: the safety, stability, and overall wellbeing of sex workers themselves. A way out of this structure/agency impasse has, more recently, been opened by an approach to sex work that seeks to reconceptualise sex work as, in the last instance, a form of labour (Weitzer, 2007). Before exploring this alternative conceptualisation, it is worth looking at how both 
oppositional and (many) supportive feminists have conceived of sex work. Both accounts draw on a notion of sex as either destructive or liberating. It is a source of empowerment or total negation of the seller's image, the site of depersonalisation and even the very premise of patriarchal violence.

Oppositional feminist stances on sex work highlight the degree to which women's involvement in the industry is a unique case of patriarchal and capitalist control of the female body and sexuality (Jeffreys, 2003; Miriam, 2005). Men's "purchase" of access to women for intercourse is a fundamental example of how capitalism, in line with the Marxist critique, allows for the exploitation of the worker's surplus labour. As Marx notes, labourpower - i.e. people's capacity to work - becomes alien to them; it confronts them as something outside themselves - a commodity. For abolitionist feminists, sex is a particularly detrimental thing to commodify, akin to one's body becoming alien to oneself. Of course, they forgo that Marx wrote of sex work as one example of the "general prostitution of the proletariat" - an iteration of a general process occurring on multiple fronts, commodifying body and matter alike and bringing them unto market relations. The main difference between Marxists and abolitionist feminists is the implicit acceptance of other forms of labour as more worthy than sex work. Feminists (and conservatives) who reject sex work, reject it on the basis that it is particularly degrading to one's status, that its conditions could never be amenable to reform. Such viewpoints are exemplified by the fact that exit programs are suggested by most oppositional feminists (Jeffres, 2008, p. 207).

As a reaction to these views, some feminist scholars working on sex work have conceived of it as subversive and a form of resistance against male hegemony (Chapkis, 2013; Pheterson, 1989; Strossen, 2000). They have highlighted the financial and psychological benefits women accrue from their entry into sex work. In this view, women's entry is seen in a positive light, not unlike their entry to other fields of work. It is a form of "sexual generosity" - a job teemed with the provision of pleasure, and the exploitation of the buyer (Queen, 2001). Sex is valorised as something that transcends the monotony of general wage labour. It is in this formulation an exception to the general condition of proletarization. These feminists normalise the value of work, foreclosing necessary reforms demanded by sex workers to safeguard them from the particularity of their work conditions.

Both perspectives on sex-work are limited in so far as they are each built from armchair theoretical considerations and seminar room debates with little empirical descriptions of the sex work industry itself and of women's lives within it. This limitation naturally leans toward a philosophical approach that has tended to silence the messiness of social reality. Secondly, and as a related limitation, these accounts have little relevance to activists, sex workers, and policymakers themselves. They offer responses that tag along the line of "abolish or celebrate sex work," which does not deepen our understanding of phenomena nor how to make it work better for the sellers.

Since the late nineties and early 2000s, approach to sex work has redefined the issue as one concerned with labour markets mediated by both legal frameworks (state regulation of the industry) and social conditions (male dominance, socioeconomic conditions) (Kempadoo \& Doezema, 2018; Scoular, 2004; Weitzer, 2007). These approaches have been productive: they aim at bridging the gap between sociological theory and policy 
by taking both patriarchy and state law into account as a dynamic milieu which interacts to shape the position of sex workers within any given society (Weitzer, 2007). These approaches insist upon multiplicity: sex work looks different on account of whether that work is performed by a woman, man, or transgender person. It is impacted by where it is done, i.e. on the street or indoors, and whether profits are syphoned up by a pimp or madam or recouped by the seller alone. An insistence on variance within the industry reflects a deeper engagement by researchers with sex workers themselves (ibid).

Sex workers themselves have published their accounts of how their jobs should be viewed. For instance, Molly Smith and Juno Mac's Revolting Prostitutes (2018) mentions a meeting with a Scottish member of parliament who asked sex workers why they choose prostitution as a career. Some explained that they were supporting their families, a transwoman admitted that she lost her job upon transitioning, and a gay man said that it was the loss of familial support that made him consider the job. To the parliamentarian's astonishment, financial concerns were paramount. It was as if, Smith and Mac write, people continue to expect jobs to have a fulfilling transcending meaning, a passion that exceeds the monetary gain.

Ethnographies and blogs that detail the experiences of sex workers often repeat the same mantra: the conditions of sex work are highly contingent on a set of legal, economic, and social conditions - they are never the same. Admittedly, it is ludicrous to suggest that a sex worker operating from her private property in San Francisco dealing sex work to men working in Silicon Valley is no different to a person selling sex from a rented apartment in the outskirts of Beirut to someone they met online.

The anthropological and historical literature on sex work has also attested to the fact that the industry arises to greater commodification of life. It is no wonder that prostitution was paramount in ancient cities, where people's social relations were defined by commerce and access to purchasable goods. The scripts of Gilgamesh speak of Shamhat, a sacred prostitute who would entice men to abandon the savagery of wildlife for the fruits of Mesopotamian civilisation. In the writings of Nils Ringdal, the only way for Ancient Greek women to attain freedom was through sex work (2007). The profession became more hegemonic in times of significant urbanisation, dissolution of familial structures, and higher rates of waged labour (ibid., 27).

Why did social reformers portray sex work as a social ill in the $20^{\text {th }}$ century, raising concerns about hygiene, "perversity," and a decline in morality? If historical work is accurate, the discourse of social reformers reverses the trajectory of this matter: people tend to take up sex work because family structures and patriarchal entities themselves fail to provide for everyone. Yet, when early social reforms brought up the "problem" of sex work, it was about protecting male soldiers, workers, and the general morality of urban space (c.f. Hammad, 2016). Sex work is imagined as a contributor rather than a symptom of more substantial structural decline. It is in the reformist view a catalyst rather than a response.

One anthropologist documents this very process among the Huli of Papua New Guinea. Huli people often paid exorbitant bridewealth upon marrying. Holly Wardlow conducted her study during a time of increased male migration to mining towns, where men would leave their wives home alone while barring them from moving freely outside their homes (2006). Women would speak of being "locked in" due to the fear of being 
assaulted if moving around town unaccompanied by a man. In case of assault, they found themselves abandoned by their kinship structure, as their partners and families did not bother helping them with litigation. With the failure of patriarchal reciprocity - that is when women feel they have not received their fair share of the family wealth in exchange for the labour that they have put in, men and family members are interested in women only as far as they secure them bridewealth, and women respond by mobilising their sexuality for their gain. Many women turned away from marriage, mainly to become "passenger women" (women who exchange sex for money), "removing their bodily capacities from the custody of clan or husband by exchanging sex for money and keeping the cash for themselves" (ibid., 149). Women are said to have "eaten their vagina," i.e. consuming the sexuality that was "meant for their families and clan."

If sex work emerges as a response to precedent deficiencies in the allocation of resources and the capacity of women to secure their safety and wellbeing - then we cannot treat it as an isolated phenomenon that acts upon the status of those engaged in it. What is perhaps different about sex work is the threat it poses to our mainstream conception of what is public and what should remain private (c.f. Day, 2007). Many forms of sex work, for women especially, is ultimately about the commodification of intimate relations, relations which to most of us often maintain explicit and intricate rituals to make appropriate. To make "sex" into something purchasable hits us as particularly alienating as if the last vestige of human dignity has fallen into the logic of market and consumption. Of course, this is far from the truth: sex work, despite its changing facets, has been endemic to human civilisation. If the commodification of "sex" and the "body" is so aggravating to feminists, we must ask about the root inclination to commodify rather than isolate one case as our only cause.

In this conception, sex trafficking is an exceptional and highly exploitative form of sex work - not unlike the exceptional labour conditions imposed on domestic workers in Lebanon and the Gulf. Sex trafficking is sex work reformulated purely for the interest of the consumer and the people profiting from the sex worker's labour. To say that sex trafficking is ultimately an exceptional form of sex work is not to confuse the two. Indeed, right-wing moralistic groups and oppositional feminists (Kafa included) have insisted on the collapsing of sex trafficking into sex work - seeing the latter as evidently leading to the former. Yet Lebanon's criminalisation of sex work has not diminished the prevalence of sex trafficking. Instead, it is the illegality of migrant labour, the limits on their work rights, and the economic vulnerability brought by the looting and banditry of the Lebanese state that places people in conditions that make them prone to sexual and labour exploitation. The similarity between the two is also constructed on the premise of there being no such thing as voluntary sex work. This second argument is equally dubious: people generally find great dissatisfaction in their work despite the respectability of their job, and there is no way to prove whether someone is genuinely coerced if they claim that they are making a choice. In this case, it remains a moral and political duty to improve the labour conditions of those who constitute part of the labour market for sex work.

\section{Lebanon, Sex and Kafa}

The Lebanese state displays a complex and often confusing stance on sex work. The state first legalised the industry in 1931 under the French mandate. During then, certain brothels were given the legal permission to 
operate, vaccinations and check-ups were mandated weekly, and the government classified workers through a two-rank tier (Khalaf, 1965). Virtually little is known of the lives of sex workers between that period and now. One reason for this is the fact that the sex workers were in precarious legal position when the government stopped issuing legal licenses for sex work in the 1970s. A myriad of laws govern the soliciting of sex, and sex workers can be charged with penal codes relating to the promotion of sex work or even public indecency (Saleh \& Qubaia, 2015). The shame and guilt regarding sex work are engendered by the very state laws that operate to "safeguard society."

However, "Super Nightclubs," a pseudonym for strip clubs, continue to openly employ sex workers under an "artist visa schema." These clubs operate with the complete awareness of both local Lebanese communities and the state, and they are regulated through directives from the ISF (Kafa 2014: 10). In an article published in Foreign Policy (Anderson, 2012), the journalist could speak to one of the workers, Linda, while her boss was present. Linda appears to be depressed in the article, complaining that coming to Lebanon was "the biggest mistake of her life." (Anderson, 2012). The article reveals that most of these migrant's mobility is controlled by their employers, who often retain their passports, and encourage them to have sex with their client. Legal and economic control over these women also silences them for fear of deportation. Often, sexual intercourse with clients occurs during the free time allocated to these women, absolving night club owners who employ them from legal prosecution and making it squarely the fault of the workers. This exceptional legal prefiguration combines illegality, and the depoliticisation of the matter (by referring to unelected officials of the General Security branch of governments to regulate it) establishes this form of state-sanctioned sex work in Lebanon as a profit-making industry for the state and tourism industry at the expense of those doing the actual work.

Behind this complex web of legal disavowal and deregulation stands a simple fact: the legal and social burden of the state-sanctioned industry is placed upon sex workers. Harsh migration laws place migrant workers in the legal custody of their employers, giving them complete control over the mobility of their employees. Any "illegal" activity tends to be restricted to the workers' "off-time," during which they work for the employers but remain legally culpable for the act. We have a state that empowers the employer over the status of the employee. This positioning effectively transforms sex workers into sex slaves by reinforcing totalitarian control over the body, time, and mobility of the worker.

In April of 2016, during the Easter Holidays, a group of women caught in a sex trafficking ring planned their escape from the Chez Maurice "Super Night Club" in Ma'amelten. The town of Ma'amelten is known for its brothels and the availability of purchasable sex (Anderson, 2012). Following their escape, they caught a minivan to Southern Beirut, where they were redirected to the police. The Internal Security Forces' raid on Chez Maurice exposed a horrific situation: seventy-five women were locked up, tortured, and forced to have sex with customers to collect "tips." In addition to the guards, owners, and rape facilitators, a doctor was locked up for undertaking more than 200 abortions on the trafficked women from the unprotected sex they endured (Human Rights Watch, 2016).

${ }^{1}$ A visa issued for foreign "artists" that is also used by migrant sex workers to come work in Lebanon. 
The ISF classified these raids as a publicity success despite warnings from Human Rights Watch (HRW) regarding the inefficiency of the Lebanese judiciary system in dealing with sex trafficking (2016). Only two years after the incident in Ma'amelten, HRW was proved correct. Middle East Eye announced that a senior police officer from within the morality unit was convicted for involvement in trafficking themselves (2018).

Within the same spirit of total rejection of sex work as a viable means of work, Kafa responded, in 2016, to HRW's sympathetic language toward the decriminalisation of sex work by positing a relationship between legalised sex work and increased sex trafficking (2016). An excerpt from their response reads: "decriminalising the entire sex trade means moving forward with regulating it and consequently legalising the practice of pimping." Here it becomes pertinent to examine the link between sex work and sex trafficking. For Kafa, the state must act as a better policeman, capable of safeguarding women (and they mainly concern themselves with women) from the dangers of sex trafficking. Yet is it not true that the Lebanese state actively "pimps" people into sex trafficking without needing to decriminalise sex work? Indeed, the ambiguous legal status of sex work and the legally enshrined right of the employer over migrants facilitate sex trafficking. The women who were brought into the country were tortured by a member of the Syrian air force Intelligence (Shaheen, 2016b). Moreover, they were brought into Lebanon based on legal employment as restaurant workers. They were cherry-picked based on their vulnerability - knowing that they could get away with trafficking if their families did not ask for them. The biggest fear of the sex traffickers was the existence of a kin network that would ask about the women, not "a state" that would prosecute them.

If Kafa saw the problem of sex work as a problem of labour, better solutions might follow. In the struggle to stand in solidarity with sex workers, we must understand the whole web of laws, policies, and contingencies which shape their entry into the industry and their transformation from mere workers to trafficked victims. The difference between the two is contained within the laws of kafala, which place workers at the mercy of their employees - making them economically and legally dependent on their approval. It also depends on the cultural and social stigma that sex work seems to bring workers, forcing them to undertake their business in secret, or else face retribution from their families and friends. If the movement opts for a stance that operates from the premise that "sex work" is as legitimate as any other, we might start to work against the socially stultifying effects of shunning sex workers. We may be able to lay the foundation for a struggle that enshrines worker's rights to maintain all the profit they accrue from their work, for sex workers to undertake work from the safety of their homes, with the support of a labour union and a supportive feminist alliance.

\section{The Demand for Sex Work?}

The report, published in 2014 by the group, looks at the "motivation, socioeconomic factors and ideological stances on sex work" of those who buy sex commercially from sex workers in Lebanon (Kafa 2014). Their website states that they are the first Lebanese organisations to target demand as the root cause of sex work, much akin to oppositional feminists discussed above. After finishing the report, it was mainstreamed through TV awareness campaigns, university lecture visits, and public events. 
Not all feminist groups in Lebanon agreed with the characterisation and coverage of the 2016 sex trafficking debacle that took place in Ma'amelten, nor with Kafa's 2014 report. Some have complained of the collapsed distinction between sex workers and sex-trafficked women (R; Yusra \& A; Sara, 2016). Importantly, an activist illumination of the lives of trans sex worker has insisted that Kafa's report ignores the queer community's reliance on sex work in their bid to increase the policing of the industry (Saleh \& Qubaia, 2015). These are worthy criticisms: Kafa's work and reporting position sex work as an attack on the status of women, completely disregarding the fact that the same laws and police departments criminalise male and trans sex workers.

Kafa's policy recommendation, research, and advocacy plans have dominated civil society's position on sex work in Lebanon. As a personal anecdote attesting to this fact, when I was an undergraduate member in the Lebanese American University's (LAU) "intersectional feminist club," we attempted to organise a talk on sex workers' rights. Despite reaching out across Beirut to multiple rights-based advocacy organisations and feminist initiatives, it was only Kafa that was willing to come and speak.

Kafa's sixty-page report begins with a paragraph that frames the industry as a direct outcome of male demand. The study builds its argument based on interviews with fifty-five men who purchased sex work at least once (Kafa 2014: 14). The report asks these clients questions about the whereabouts, reasons, and methods of procuring sex. It then goes on to frame the problem as mainly emanating from the source they have diagnosed. Clients are represented as the single factor from which springs the sex work industry. From these premises, the report goes on to demarcate the demand of men for purchasable sex as the driving factor for the predicament that is sex work. For the authors of Kafa's report, without such demand:

... there would no supply of women for prostitution purposes, there would be no pimps or traffickers recruiting and managing women and girls to meet the varied needs of the prostitution buyers, and there would be no businesses and individuals operating nationally or trans-nationally to recruit or traffic women, eventually rendering the individuals and industry that profit from the sexual exploitation of women and girls obsolete. (KAFA, 2014:12)

Given how the problem is framed - as one of male demand - the logical conclusion is that abolishing the sex trade will be achieved through penalising men's access to sex work by criminalising the client and legalising the worker. This is often referred to as the Nordic Model, as it originates in Sweden. It is no surprise that the rest of the report fixates on the misogynistic and ill-informed accounts given by clients on why men buy sex and how sex workers ought to behave. The report operates as a short circuit, immediately announcing the source of the problem then going on to investigate its origin and finding it where they said it would be.

Kafa assumes that by demonising people's incentive for purchasable sex and deconstructing their biological justification for sex work, they can, in turn, persuade the state to criminalise clients and thereby reduce sex work. This strategy risks placing Kafa within the folds of conservative and moralistic right-wing movements that reject sex work on the same premise of its inherent moral vice. Moreover, this presumption cleanses sex 
work from the structural factors that situate it, such as the relationship between economic opportunity, access to marriage, and the taboo surrounding sexual activity in Lebanon.

The report includes several pages dedicated to highlighting interviewee responses as to why sex work exists (Kafa 2014: 31) and why men pursue it: "God has granted the sexual impulse to men." (ibid 35). Or simply what they seek in a woman: "I wanted to experience buying prostitutes and having sex with someone other than my wife. My friends were with me, and they advised me to try it." (ibid: 37). All the answers are then copied in verbatim in large fonts across the report to paint a picture of the client as key. It is clear what the intention of such word placement is: fearmongering of dissident working-class male sexuality. By positioning the client's voices as patriarchal, sexist, or particularly aggressive, what we observe is a theatrical positioning of the problem at bay: only sexist comments made by the men, not the narratives of the women who went into sex work, their decision-making process, their desires, needs, or wants - whether they want to remain in the business or leave entirely. In highlighting these voices, Kafa creates an image of the consumer as a violent creator of the sex industry.

What follows the quotes mentioned above are recommendations, and a page with this sentence: "... the risk of being legally penalised might be the most effective tools to discourage men from buying and using women for sex work purposes." (Kafa 2014: 56).

Some feminists have condemned this viewpoint for overvaluing men's position and role within the industry and marginalising sex workers' ideas about their labour (Kesler, 2002). It is no surprise then that even when feminist organisations like Kafa attempt to study sex workers' issues empirically, they often emphasise a plan premised on the demonisation of clients, at the expense of silencing female sex workers who might have a different take on their work. What is then missing from the report is the voices of the women selling sex work themselves and the background of the men purchasing the sex. Instead of asking why women might go into sex work, the report sees sex work as a direct causation of men's sexual desire. Or as Ghada Jabour, the principal author listed on the report, has once said: "[e]verything evolves around the sexuality of men" (Shaheen, 2016a).

What occurs throughout this report is the fetishisation of the sexual desire of men as the sole harbinger of misery and violence upon sex workers. It is as if for the authors of the report, there is no labour law, no state to regulate, or a socioeconomic structure that brings both client and worker together. Instead, the story unfolds from the tip of the man's desire and concludes there. It is through weaving such a narrative that Kafa can advocate prohibiting the purchase of sex work. Ultimately, we learn more about the lives of men purchasing sex than we do of the women selling it. The problem of sex work is portrayed as no longer that of labour condition, poverty, and abuse - it is merely a matter of distaste: how could the client have said such thing about the prostitute? How could foreign men be buying their access to the bodies of women? Moralistic (and arguably patriarchal) instincts are conjured to claim that sex work is an intolerable (and hence nonreformable) industry. 


\section{Strategies \& Recommendations}

Having outlined the problematics of Kafa's conceptualisation of the issue at hand, what would a reimagining of the issue of sex work as a social phenomenon that doesn't obfuscate its material condition look like? It would mean recognising that women might be reluctant to leave the industry and grappling with why that might be the case. On this front, ethnographic literature on sex workers suggests that women in sex work experience more control over their wage, mobility, and stability within the industry rather than outside of it as workers within mainstream jobs (c.f. Towne \& Brennan, 2004). Greater control is especially the case when exit from sex work is usually an exit into a traditional heterosexual marriage, unstable waged labour, and new forms of dependency (ibid). It is these same conditions that the people who entered the business sought to abandon.

When Kafa promotes its abolitionist model, it does so on the premise of the success of the Nordic Model. The model, implemented in Sweden, Norway, and Finland, criminalises the purchase of sex. As the Finnish sex work advocate Essi Thesslund makes clear, this policy operates by inviting the state to criminalise buyers by surveilling sex workers. The policy model itself operates on the premise that all sex workers can be reallocated jobs or reintegrated into educational institutions. It fundamentally does not take into account the messiness of the social situations that lead into sex trafficking in Lebanon: dire migration rules, homophobia and transphobia that excludes people from the job market, and the sheer incapacity of the labour market to offer anyone without nepotism an entry. The "Nordic" model operates within a "Nordic" economy, with generous welfare benefits, free education, unemployment benefits, and healthcare. To implement it in the sectarian and crony capitalist Lebanon without looking at the structural transformation is misguided, to say the least.

One of the most popular responses to sex work in this model is the exit programs. They are premised on the inherent value of non-sexual work. It is difficult to imagine such work conditions existing anywhere, much less in a country in the midst of a financial crisis and revolutionary upheaval. To be fair to Kafa, their report was published four years before the recent uprising. Yet, the country has struggled with financial woes and placed obstacles on employment for an extended period. Migrant workers from Syria, Bangladesh, Sri Lanka, and Ethiopia have been some of the worst affected by the general lack of worker's rights - as they are even excluded from the barely implemented rights that do exist.

So how do we rethink a "strategy" for enacting solidarity with sex workers and people who inadvertently might become trafficked? First, we must recognise that in the coming days, the worsening economic situation will likely drive more individuals into sex work and create conditions that make exploitation more palpable. The response should not be to attempt to criminalise the buying and selling. This move would simply decrease the opportunities for sex work in general, without an alternative conceivable within the economic conditions - it is akin to telling sex workers to return to conditions of alienation and imposition that they sought to leave in the first place. We should instead look at making sex worker's conditions the safest they can be. This includes full decriminalisation, unionisation, provision of testing, and protection. 
Secondly, we must deal with the laws that exclude foreign men and women from labour protection. These conditions create a subset of people that are more exploitable than citizens, and a legal differentiation that harms migrants but also builds the façade of a differentiated native labour force. This differentiation impedes our capacity to create solidarity between workers but most importantly contributes to the worsening of terms of labour - as people's legality and ability to live in Lebanon becomes dependent on acquiescing to harsh working conditions.

This follows in line with the problem of sex trafficking. Kafa has long attempted to force the state to prosecute sex traffickers and not people (usually women) that are trafficked. The case of Johnny Haddad, the police officer indicted of sex trafficking charges while working on the anti-trafficking unit shows the liability of the state in sex trafficking. The fact that the state allows the ambiguous legal space for "super nightclubs" to exist, while officers facilitate the release of sex trafficked victims from prison without due process (c.f. Shaheen, 2016) shows that the state plays an active role in creating the conditions of tolerance for the proliferation of inhumane treatment of sex workers and sex-trafficked individuals. In response, we must abandon work with the sectarian state as it stands and position ourselves with a total overhaul of state management of sex work. Instead, we must propose our law models that decriminalise sex work, protect migrant workers, and criminalise inhumane work conditions. These "laws" cannot be implemented within the boundaries of a sectarian warlord's state bent upon accumulating wealth for its patrons and followers. The solution is only within carrying the current revolution's aims of toppling the sectarian state as it is and replacing it with a humane alternative.

More so, Kafa's solution of an exit program ignores completely that refugees and migrants are a central part of the sex work community in Lebanon. By highlighting 'sex' as the problem in sex work, Kafa ignores how the racist anti-refugee stances of the Lebanese state create perfect conditions of exploitation among migrants no matter what they do. Even if women's employment in mainstream jobs is considered more "humane" and less exploitative than sex work, sex workers themselves have not been asked. Indeed, the Kafa report omits the voices of women, and their desires, needs, and stories that might complicate the picture that Kafa is painting. Given that an alternative to sex work is not realistically possible, and that sex workers might not reject the idea of improved conditions - why not accept that these conditions are amenable to change?

Without a viable labour market, it seems most realistic to advocate for the decriminalisation of the sex work industry writ large, and in line with that implement new labour laws that penalise exploitation and trafficking. With a mobilisation approach, the forging of a sex worker's union in Lebanon would open space for workers to engage in collective bargaining with employers and the state. This is integral if Lebanon is to lose its "super nightclub" hold on the industry. A union would encourage healthy and democratically driven policies that are key to improving conditions and ensuring that exploitation and trafficking are diminished. It would create another social entity against the state's control of labour relations.

Finally, more ethnographic research ought to be commissioned by civil society actors so that they might understand more comprehensively the issues and constraints of sex work as both a labour and feminist issue in Lebanon. Such work is capable of uncovering exploitation and persistence of the industry that statistical 
report often fails to cover (Östergren, n.d.). Fieldwork is better placed to grasp the processes of women's entry into sex-work by documenting life histories from sex workers themselves (National Task Force on Prostitution, 2008; Towne \& Brennan, 2004). Most importantly, a research project that centres sex workers' demands and self-defined issues constitute a more ethical and democratic form of intervention from civil society.

\section{Conclusion}

In studying "sex work" as a phenomenon that raises from the contingencies of migration, labour, and gender relations, it is more akin to a proper and comprehensive analysis. I have argued in this paper how such a conception can help us move beyond moralistic attitudes that tend to rely on a reactionary and fetishistic understanding of a complicated and overwhelmingly political situation. What can be learned here is that sex work is not different from any form of work. What differentiates it from forced sex work is the conditions that allow for employers to act with impunity, particularly the state's disregard of workers that it deems expendable. It is here that we find why migrants and LGBT people are overrepresented in the sex industry: they are more likely to suffer from obstacles while entering the labour market. These obstacles, in addition to the general exclusion from kin-based networks of support, make them particularly vulnerable to exploitation in general. In a country with weak access to education, it is no wonder that people find in their bodies a way to make wages and survive.

What should be our response as activists and feminists? First, we must stay away from taking models developed in wildly different contexts and hoping to implement them here without adjustment. The refugee crisis, the absence of anything resembling a welfare state, and the rampant sexism and homophobia that the Lebanese state law exudes are remarkably salient for the issue of sex work. Even if we hypothetically agreed that our goal is to eliminate sex work, we must think about what this means in a condition of perennial unemployment, a destroyed economy, and no labour protection across the board. We must also evaluate our stance towards reforming the state, knowing fully well how great the state has been in perpetuating pimping through its security services and disregard of anti-trafficking law.

I have picked Kafa's work not because of its deficiencies but because of how it embodies two tendencies that I find critical. The first is laying the blame on the "demand" side of the equation, and the second is to buy into the Nordic model. These two tendencies are akin to the fetishisation of men's sexual desire - giving a creative force which it lacks and inadvertently takes away from the state's role in creating conditions for worsening labour rights and corruption writ large. Their model readily does away with the existence of trans and gay sex workers who might find that their clients are already criminalised under penal codes which prohibits nonheterosexual relations. Instead, I pointed to a more holistic approach, one that considers the social relations which give rise to sex work and which must at least be dealt with if we wish to abolish it. Without this holistic labour approach, our attitude becomes moralistic, concerned more with the sexual undertones of work than the status of the people involved - rescuing a fabricated image of moral dignity at the expense of the violence 
that permeates the world of sex workers today. This is urgent in the politically turbulent time of today's mobilisation and uprising. 
Kohl 6.1

\section{References}

Abi Samra, M. (2019). The Chez Maurice Case: Media and NGO. SOAS Law Journal, 5(1), 11-39.

Anderson, S. (2012, February 9). Sex for Sale in Beirut - Foreign Policy. Retrieved May 13, 2020, from Foreign Policy website: https://foreignpolicy.com/2012/02/09/sex-for-sale-in-beirut/

Bazi, I. (2019). خلف جدران أكثر بيوت الدعارة صخباً خلال السنو ات المجنونة في بيروت. Retrieved September 9,

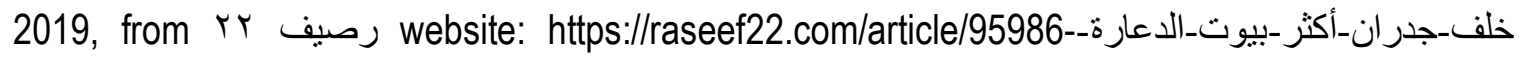
صنباً_خلال

Chapkis, W. (2013). Live sex acts: Women performing erotic labor. New York: Routledge.

Day, S. (2007). On the game: Women and Sex Work. London: Pluto Press.

Hammad, H. (2016). Industrial sexuality: Gender, urbanization, and social transformation in Egypt. Austin: University of Texas Press.

Jeffreys, S. (2003). Sex tourism: do women do it too? Leisure Studies, 22(3), 223-238.

Jeffreys, S. (2008). The Industrial Vagina: The Political Economy of the Global Sex Trade. London: Routledge. https://doi.org/10.4324/9780203698303

Kempadoo, K., \& Doezema, J. (2018). Global sex workers: Rights, resistance, and redefinition. New York: Routledge.

Kesler, K. (2002). Is a feminist stance in support of prostitution possible? An exploration of current trends. Sexualities, 5(2), 219-235.

Khalaf, S. (1965). Prostitution in a Changing Society. Beirut: Khayats.

MEE. (2018). Senior Lebanon morality police officer arrested for prostitution links: Report | Middle East Eye.

Retrieved September 6, 2019, from Middle East Eye website: https://www.middleeasteye.net/news/senior-lebanon-morality-police-officer-arrested-prostitutionlinks-report

Miriam, K. (2005). Stopping the Traffic in Women: Power, Agency and Abolition in Feminist Debates over Sex-Trafficking. Journal of Social Philosophy, 36(1), 1-17. https://doi.org/10.1111/j.14679833.2005.00254.x

Nasr, S. (1978). Backdrop to Civil War: The Crisis of Lebanese Capitalism. Merip Reports, (73), 3-13.

National Task Force on Prostitution. (2008). Writings by women in the sex industry. San Francisco: Cleis Press Start.

Pheterson, G. (ed.) (1989). A Vindication of the Rights of Whores. Seattle: Seal press.

Östergren, P. (n.d.). Sexworkers Critique of Swedish Prostitution Policy. Accessible at http://www.petraostergren.com/upl/files/115326.pdf

Queen, C. (2001). Sex Radical Politics, Sex-Positive Feminist Thought, and Whore Stigma. In: Rayan, B. (ed), Identity Politics in the Women's Movement, 92-102. New York: NYU Press.

R, Yusra, \& A, Sara. (2016). Migrant Worker Repression and Solidarity in Lebanon. Retrieved September 14, 2019, from Jadaliya website: https://www.jadaliyya.com/Details/33682

Ringdal, N. J. (2007). Love for Sale: A World History of Prostitution. New York: Grove/Atlantic, Inc.

Rubin, G. (1993). Misguided, dangerous, and wrong: An analysis of antipornography politics. In: Assister, A., \& Carol, A. (eds), Bad Girls and Dirty Pictures: The Challenge to Reclaim Feminism, 18-40. London: Pluto Press. 
Saleh, A. J., \& Qubaia, A. A. (2015). Transwomen's Navigation of Arrest and Detention In Beirut: A Case Study (En-Ar). Civil Society Review. https://doi.org/10.28943/CSR.001.008

Scoular, J. (2004). The subject of prostitution: Interpreting the discursive, symbolic and material position of sex/work in feminist theory. Feminist Theory, 5(3), 343-355.

Shaheen, K. (2016a). Dozens of Syrians forced into sexual slavery in derelict Lebanese house | World news I The Guardian. Retrieved September 6, 2019, from The Guardian website: https://www.theguardian.com/world/2016/apr/30/syrians-forced-sexual-slavery-lebanon

Shaheen, K. (2016b, August 1). Lebanon sex trafficking: Syrian woman describes nine-month ordeal | Syria I The Guardian. Retrieved June 13, 2020, from the Guardian website: https://www.theguardian.com/world/2016/aug/01/lebanon-sex-trafficking-syrian-woman-describesnine-month-ordeal

Smith, M., \& Mac, J. (2018). Revolting Prostitutes: The Fight for Sex Workers' Rights. London: Verso.

Strossen, N. (2000). Defending Pornography: Free Speech, Sex, and the Fight for Women's Rights. New York: NYU Press.

Towne, B., \& Brennan, D. (2004). What's Love Got to Do with It? Transnational Desires and Sex Tourism in the Dominican Republic. The Women's Review of Books, 21(10/11), 27. https://doi.org/10.2307/3880383

Wardlow, H. (2006). Wayward Women: Sexuality and Agency in a New Guinea society. Berkley: Univ of California Press.

Weitzer, R. (2007). The Social Construction of Sex Trafficking: Ideology and Institutionalization of a Moral Crusade. Politics \& Society, 35(3), 447-475.

Weitzer, R. (2009). Sociology of Sex Work. Annual Review of Sociology, 35(1), 213-234. 